\title{
SOCIAL FUNCTIONING AND SELF-ESTEEM AMONG SUBSTANCE ABUSERS AT PORTSAID PSYCHIATRIC HEALTH HOSPITAL
}

\author{
Mohammed Elsayed Elyamany $^{1}$, Amal Sobhy Mahmoud ${ }^{2}$, Nadia Mohammed Wahba ${ }^{3}$ \\ Psychiatric nursing and mental health, faculty of nursing, port-said university ${ }^{1}$ \\ Prof. of Psychiatric and Mental Health Nursing, faculty of nursing, port-said university ${ }^{2}$ \\ Lecturer of Psychiatric and Mental Health Nursing, faculty of nursing, port-said university ${ }^{3}$
}

\begin{abstract}
Background: Substance abuse emerges as a significant social issue that negatively affects social functioning, disrupts social harmony. Individuals with low self-esteem have been determined to have a tendency to substance use to control their emotions, behavior and satisfy their need for self-esteem. Aim: To explore the relation between the levels of social functioning and self-esteem among substance abusers at Port-Said Psychiatric Health Hospital. Design: A descriptive correlation research design was utilized in this study. Subjects: were comprised of a sample of 133 substance abusers (males or females). Setting: substance abusers who attended the outpatient unit through the hotline for substance abuse at Port Said Psychiatric Health Hospital. Tools: Two tools were used to collect data in this study; which were Social Functioning Scale (SFS), and Rosenberg Self-Esteem Scale (RSS), in addition to personal and clinical data structured sheet. Results: Three-quarters of the studied substance abusers had a low level of social functioning. About two-thirds of the studied substance abusers had a low level of self-esteem. Conclusion: A statistically significant positive correlation between overall social functioning and total self-esteem among the studied substance abusers. Recommendations: psychosocial intervention should be addressed to substance abusers to improve particular areas of social functioning, such as communication, interpersonal relationships, and employment. Moreover,
\end{abstract}

Key Words: Self-Esteem, Substance Abuser, Social Functioning. 


\section{INTRODUCTION}

Substance abuse refers to the destructive or hazardous use of psychoactive substances, containing illicit drugs and alcohol. Psychoactive substance use can cause dependence syndrome which suggests a set of cognitive, behavioral, and physiological phenomena that develop after repeated substance use which typically comprise a strong desire to take the drug, difficulties in controlling its use, a higher priority given to drug use than to other activities and obligations, persisting in its use despite destructive consequences, amplified tolerance, and sometimes a physical withdrawal state (WHO, 2017). Substance use is an enormously expensive and damaging mental disorder that has a significant adverse effect on personal health, family life and the environment, impacting social functioning negatively (Aditi \& Arunjyoti, 2018; Ersöğütçü, \& Karakaş, 2016).

Social functioning can be described as the ability to communicate with the social environment, in a manner that is generally accepted as normal. Impaired social functioning may comprise poor social interactions, difficulties in maintaining relationships, and impaired work-related functioning (Van Kleef, Van Donkersgoed, \& de Jong, 2015). The problem of substance abuse contributes to medical or psychiatric conditions, disability, and death as a result of accidents or illnesses caused or deteriorated by substance use, or greater rates of suicide, all of which affect society. Substance abusers reported decreased social functioning with their friends and families, reduced interest or enjoyment in their leisure activities, less autonomy to maintain duties, poorer cognitive functioning, lack of social skills, and engagement in social activities (Daley, 2013).

One of the most significant indicators of psychosocial health is self-evaluation. Self-esteem, which characterizes the emotional dimension of the self, means selfacceptance, self-approval, self-respect, and self-assessment regarding one's own values. It has been established that people with poor self-esteem have susceptibility for drug use in order to fulfill their desire for self-esteem to maintain self-esteem and to regulate their feelings and behaviors (Ersöğütçü \& Karakaş, 2016). 
Substance abuse nursing and psychiatric nurses have a decisive role in substance abuse. They can aid at any level of substance abuse and have stronger and more regular interactions with substance abusers than other health care providers' .So; their performance can have a high effect on the substance abusers' attitudes and treatment efficacy. They are usually the key source of support for substance abusers and their families throughout stress to safeguard and comfort the substance abuser and not just to treat their illness (Ebrahimi, Navidian \& Keykha, 2014).

\section{SIGNIFICANCE OF THE STUDY}

Substance use disorder, such as alcohol, nicotine, and illicit drugs, is one of the largest public health issues in the world (China National Narcotics Control Commission, 2013). An Egyptian study revealed that $19.1 \%$ of the population is regularly using substance whereas tobacco smoking was excluded (Hamdi et al., 2016). According to the National Institute of Drug Abuse (2008), abuse of substances affects physical, mental, academic, interpersonal relationships, psychological and social functioning. Abusers have serious personal and social problems, including school failure, crime, family violence and abuse. Therefore, this study shed light on exploring the relation between the levels of social functioning and self-esteem among substance abusers. The majority of abusers had lack of knowledge about abuse substance and need health education to prevent it and if occurring abuse how prevent it and rehabilitation.

\section{AIM OF THE STUDY}

The study aimed to explore or assess the relation between the levels of social functioning and self-esteem among substance abusers at Port Said Psychiatric Health Hospital.

\section{SUBJECTS AND METHOD}

\section{Design:}

A descriptive correlational research design was utilized for the current study.

\section{Setting:}

This study was carried out in psychiatric outpatient clinics through hotline for substance abuse at Port Said Psychiatric Health Hospital. The hospital is affiliated to 
General Secretariat of Mental Health and Addiction Treatment (GSMHAT), Ministry of Health. The hospital provides care to psychiatric and substance abuse patients. The hospital capacity is 140 beds; serves three Governorates namely Port-Said, El-Ismailia, and El-Suez. The hospital comprises five inpatient psychiatric departments and one men's department for substance abuse (12 beds). Additionally, one outpatient clinic for children and finally psychiatric outpatient clinic which is accessible all days of the week from 10 a.m. to 2 p.m. It consists of three rooms specialized for treatment, the first room comprised two psychiatrists, the second room for consultant specialized in psychiatric treatment and lastly the third room comprised two nurses who are assisting in treatment.

\section{Subjects:}

The study subjects was a sample of 133 substance abusers (males or females) attended the outpatient clinic through hotline for substance abuse at Port Said Psychiatric Health Hospital.

\section{Sample Size:}

The sample size was determined using the following equation (Dobson, 1984)

Sample size $(\mathbf{n})=\left(\mathrm{z}^{2} \div \Delta^{2}\right) \times \mathrm{P}(100-\mathrm{P})$

\section{Where:}

Za/2: A percentile of standard normal distribution determined by $95 \%$ confidence level $=$ 1.96

$\Delta:$ The width of the confidence interval $=7$

P: Prevalence of Substance Abuse in Egypt = 19.1 (Hamdi et al., 2016).

Sample size $(\mathbf{n})=\left(1.96^{\mathbf{2}} \div 7^{2}\right) \times 19.1 \times(100-19.1)=\mathbf{1 2 1}$ substance abusers

The calculated sample size is 121 substance abusers. Due to the design effects (2.422), expected non-participating rate (10\%), the final sample size was $\mathbf{1 3 3}$.

\section{Tools for Data Collection:}

To collect data for this study, the following tools were used:

\section{Tool I: Social Functioning Scale (SFS):}


This scale was developed by Birchwood, Smith, Cochrane, Wetton \& Copestake (1990), in an English language and translated by Atta, (2017) in an Arabic language to assess the levels of social functioning of individuals diagnosed with substance abuse. The SFS contains 76 items that covered 7 dimensions which including social withdrawal/engagement (5 questions), interpersonal functioning (4 questions), and work / employment (4 questions), answers of the participants for these questions were scored on a value ranging from "0" to "3". Additionally, independence performance (13 items), independence competence (13 items), recreational activities (15 items), and pro-social activities (22 items). Responses of substance abusers for these dimensions were measured on 4 points Likert scale; ranged from "0" to "3". The scores ranged from 0 to 15 for social withdrawal/ engagement, 0 to 9 for interpersonal functioning, 0 to 10 for work/ employment, 0 to 39 for independence performance, 0 to 39 for independence competence, 0 to 45 for recreational activities, and finally 0 to 66 for pro-social activities, with a total score ranging from 0 to 223 . The social functioning was considered to be high if the percent score was equal or more than $60 \%$, and low if less.

The Arabic inventory of SFS showed validity and high Internal consistency, with Cronbach's Alpha $\alpha=0.91$. Validity was done by a jury of experts who decided that the scale is valid (Atta, 2017).

\section{Tool II: Rosenberg Self-Esteem Scale (RSS):}

This scale was developed by Rosenberg (1989), in an English language and translated by Zaidi, Awad, Mortada, Qasem \& Kayal (2015), in an Arabic language. It was consisted of 10 item scale that measures global self-worth by measuring both positive and negative feelings about the self. All items were responded using a 4-point Likert scale format ranging from strongly agree (3) to strongly disagree (0). Items were scored 3, 2, 1 and 0 for the responses "strongly agree", "agree", "Disagree" and "strongly disagree" respectively. The scoring was reversed in the negative statements (items 2, 5, 6, 8, and 9). The total score ranged from 0 to 30. Scores between 15 to 25 suggested high self-esteem, while scores below 15 suggested low self-esteem. Reliability: The scale had an acceptable internal consistency with a Cronbach's alpha coefficient between $\alpha 0.85$ to 0.88 . 
In addition to personal and clinical data sheet: Structured sheet was developed by the researcher in an Arabic language. The sheet elicits personal characteristics as age, sex, marital status, level of education, occupation, and income. It also included questions that cover data related to history of substance abuse such as age of initiation of substance abuse, kind of substance used, method of usage, the cause of the first dose and problems caused by substance abuse.

\section{Pilot study:}

The pilot study was conducted on $10 \%$ of study sample which included (13) substance abusers selected randomly. This was done to assess the significance, clarity and applicability of the used tools and to approximate the time required to fill out the data collection tools. The substance abusers who enrolled in the pilot study were excluded from the main study sample. Based on the findings of the pilot study, no modifications were done on the tools. It was simple and clear. The pilot study was conducted in the middle of June 2018 for two weeks.

\section{Field Work:}

Before embarking in the field work, the actual days that the substance abusers attended in psychiatric outpatient clinic through hot line for substance abuse were obtained to detect days of data collection. The data was collected through 2 days (Sunday and Thursday) per week. The collection of data covered a period of six months from the first of July 2018 to the end of December 2018. The data collection process was conducted using face to face interview technique that was done on an individual basis and this was done on a private area in the outpatient clinic to ensure privacy and confidentiality of the collected data. A number ranging from 2 to 3 of substance abusers were interviewed, from 2 p.m. to 5 p.m. Each interview lasted from 45 to 60 minutes depending on the responses of the subjects. After completion, the researcher ensured that all statements included in the tools were completed. Then, the studied substance abusers were thanked for their cooperation. 


\section{Administrative Design:}

Before starting any step in the study, a formal letter from the Dean of the Faculty of Nursing, Port Said University was sent to the Manager of the above mentioned setting requesting his permission and cooperation to carry out the present research after illuminating the purpose of the study.

\section{Ethical considerations:}

* The study protocol was approved by the Ethical Committee of the General Secretariat of Mental Health and Addiction Treatment (GSMHAT), Ministry of Health.

* An informed consent was obtained from substance abusers to participate in the study after explaining the purpose of the study.

* The studied substance abusers were informed that their participation is voluntary and they have the right to withdraw from study at any time.

* The studied subjects were ensured the confidentiality of the information collected and the anonymity was guaranteed.

\section{Statistical Design:}

Data entry and statistical analysis were performed using statistical package for social science (SPSS) version (20.0). Data were presented using descriptive statistics in the form of frequencies and percentages for qualitative variables, and means and standard deviations for quantitative variables. Qualitative categorical variables were compared using chi-square test. Fisher Exact and Monte Carlo correction for chisquare when more than $20 \%$ of the cells have expected count less than 5. Moreover, person coefficient test was used to correlate between social functioning and selfesteem among substance abusers. The statistical significance value was considered at P-value $\leq 0.05$. 


\section{RESULTS:}

Table (1): This table shows that the personal characteristics of the substance abusers revealed that the highest percentage of the studied subjects $(96.2 \%)$ was male, and more than half of them (59.4\%) aged less than 30 years. It is also observed that, the majority of them $(97.0 \%)$ were Muslims. Regarding residence, two thirds of them (66.2\%) lived in urban and marital status, $62.4 \%$ of substance abusers were single. As regard to their level of education, it was found that, $60.2 \%$ had primary to secondary level of education. According to substance abusers' occupation, more than half of them $(52.6 \%)$ were working, but the majority of them $(81.4 \%)$ were skilled workers. Also, regarding family income, $48.9 \%$ of them stated that, they didn't have enough monthly income and $69.9 \%$ were living with their parents.

Table (2): This table clarifies that more than two thirds of the studied substance abusers $(69.9 \%)$ initiated substance abuse at age of less than 20 years. Also, more than half of them (54.9\%) used more than one type of the substance. Regarding method of use of the substance, $52.6 \%$ of the studied substance abusers were using oral method in their substance abuse, while only $3.8 \%$ of them used injection method. In addition, the majority of the studied substance abusers $(85.0 \%)$ were exposed to problems due to substance abuse, $51.3 \%$ of which were family problems. According the reason for taking the first dose, around half of the studied subjects (49.6\%) reported that the reason for taking the first dose was due to bad friends, while curiosity constituted $27.1 \%$ of the subjects' responses.

Also, the majority of the studied substance abusers (85.7\%) did not complain of any physical diseases. As indicated, $40.6 \%$ of substance abusers complained of tension and anxiety. It was found that less than one quarter (22.6\%) of the substance abusers had mental illness, and $40.0 \%$ of them had depression.

Table (3): This table illustrates that the levels of social functioning dimensions among the studied substance abusers. It was observed that, the high levels of social functioning dimensions were found in interpersonal functioning $(67.7 \%)$, followed by independence competence (63.2\%), and social engagement/ withdrawal (57.9\%). Whereas, low levels of social functioning dimensions were found in pro-social 
activities, recreational activities and independence performance $88.7 \%, 86.5 \%$, and 57.9 respectively.

Figure (1): It was observed that, almost three quarters of the studied substance abusers (78.2\%) had low level of social functioning, while only $21.8 \%$ had high level.

Figure (2): It was represents that about two thirds of the studied substance abusers $(66.2 \%)$ had low level of self-esteem, while the rest of them had high level.

Table (4): This table reveals the correlation between total score of social functioning dimensions and total score of self-esteem among the studied substance abusers. It was observed evidenced that there were statistically significant positive correlations between social functioning dimensions including interpersonal functioning, pro-social activities, recreational activities, and independence performance and total self-esteem among the studied substance abusers where $(\mathrm{r}=0.284,0.267,0.248$, and 0.191$)$ respectively.

Table(5): This table shows the correlation between overall social functioning and total self-esteem among the studied substance abusers. It was notes that there was a statistically significant positive correlation between overall social functioning and total self-esteem whereby $(r=0.263)$. 
Table (1): Distribution of the studied substance abusers according to their personal characteristics $(\mathrm{n}=133)$

\begin{tabular}{|c|c|c|}
\hline \multirow{2}{*}{ Personal characteristics } & \multicolumn{2}{|c|}{ Studied substance abusers } \\
\hline & No. & $\%$ \\
\hline $\begin{array}{l}\text { Sex } \\
\text { Male } \\
\text { Female }\end{array}$ & $\begin{array}{c}128 \\
5\end{array}$ & $\begin{array}{c}96.2 \\
3.8\end{array}$ \\
\hline $\begin{array}{l}\text { Age }(\text { years }) \\
<30 \\
30 \leq 40 \\
40 \leq 50 \\
\geq 50\end{array}$ & $\begin{array}{c}79 \\
39 \\
12 \\
3\end{array}$ & $\begin{array}{c}59.4 \\
29.3 \\
9.0 \\
2.3\end{array}$ \\
\hline SD. \pm Mean & \multicolumn{2}{|c|}{$8.77 \pm 29.77$} \\
\hline $\begin{array}{l}\text { Religion } \\
\text { Muslim } \\
\text { Christian }\end{array}$ & $\begin{array}{c}129 \\
4\end{array}$ & $\begin{array}{c}97.0 \\
3.0\end{array}$ \\
\hline $\begin{array}{l}\text { Residence } \\
\text { Rural } \\
\text { Urban }\end{array}$ & $\begin{array}{l}45 \\
88\end{array}$ & $\begin{array}{l}33.8 \\
66.2\end{array}$ \\
\hline $\begin{array}{l}\text { Birth order } \\
\text { The first } \\
\text { The middle } \\
\text { The last }\end{array}$ & $\begin{array}{l}46 \\
47 \\
40\end{array}$ & $\begin{array}{l}34.6 \\
35.3 \\
30.1\end{array}$ \\
\hline $\begin{array}{l}\text { Marital status } \\
\text { Single } \\
\text { Married } \\
\text { Separated } \\
\text { Divorced } \\
\text { Widowed }\end{array}$ & $\begin{array}{c}83 \\
39 \\
4 \\
6 \\
1\end{array}$ & $\begin{array}{c}62.4 \\
29.3 \\
3.0 \\
4.5 \\
0.8\end{array}$ \\
\hline $\begin{array}{l}\text { Level of education } \\
\text { Illiterate } \\
\text { Primary to secondary education } \\
\text { University and higher education }\end{array}$ & $\begin{array}{l}31 \\
80 \\
22 \\
\end{array}$ & $\begin{array}{l}23.3 \\
60.2 \\
16.5 \\
\end{array}$ \\
\hline $\begin{array}{l}\text { Occupation } \\
\text { Student } \\
\text { Working } \\
\text { Not working } \\
\text { House wife }\end{array}$ & $\begin{array}{c}11 \\
70 \\
51 \\
1\end{array}$ & $\begin{array}{c}8.3 \\
52.6 \\
38.3 \\
0.8\end{array}$ \\
\hline $\begin{array}{l}\text { Type of employment }(\mathbf{n}=70) \\
\text { Skilled worker } \\
\text { Employee }\end{array}$ & $\begin{array}{l}57 \\
13\end{array}$ & $\begin{array}{l}81.4 \\
18.6\end{array}$ \\
\hline $\begin{array}{l}\text { Income } \\
\text { Enough and increases } \\
\text { Enough } \\
\text { Not enough }\end{array}$ & $\begin{array}{l}10 \\
58 \\
65\end{array}$ & $\begin{array}{c}7.5 \\
43.6 \\
48.9\end{array}$ \\
\hline $\begin{array}{l}\text { Living status } \\
\text { Alone } \\
\text { With parents } \\
\text { With wife and sibling } \\
\text { Friends }\end{array}$ & $\begin{array}{c}6 \\
93 \\
33 \\
1\end{array}$ & $\begin{array}{c}4.5 \\
69.9 \\
24.8 \\
0.8\end{array}$ \\
\hline
\end{tabular}


Table (2): Distribution of the studied substance abusers according to their clinical characteristics $(\mathrm{n}=133)$

\begin{tabular}{|c|c|c|}
\hline \multirow{2}{*}{ Clinical characteristics } & \multicolumn{2}{|c|}{ Studied substance abusers } \\
\hline & No. & $\%$ \\
\hline \multicolumn{3}{|l|}{ Age of initiation of substance use/years } \\
\hline$<20$ & 93 & 69.9 \\
\hline $20 \leq 25$ & 23 & 17.3 \\
\hline $25 \leq 30$ & 14 & 10.5 \\
\hline$\geq 30$ & 3 & 2.3 \\
\hline \multicolumn{3}{|l|}{ Type of substance used } \\
\hline Heroin & 8 & 6.0 \\
\hline Cannabis & 24 & 18.0 \\
\hline Tramadol & 28 & 21.1 \\
\hline More types & 73 & 54.9 \\
\hline \multicolumn{3}{|l|}{ Method of use } \\
\hline Oral amelioration & 70 & 52.6 \\
\hline Inhalation & 14 & 10.5 \\
\hline Injection & 5 & 3.8 \\
\hline More than one method & 44 & 33.1 \\
\hline \multicolumn{3}{|l|}{ Problems caused by substance abuse } \\
\hline Yes & 113 & 85.0 \\
\hline No & 20 & 15.0 \\
\hline \multicolumn{3}{|l|}{ Problems caused by substance abuse $(n=113)$} \\
\hline Outdoor problems & 15 & 13.3 \\
\hline Family problems & 58 & 51.3 \\
\hline Friends problems & 3 & 2.7 \\
\hline Relations problems & 26 & 23.0 \\
\hline Stealing problems & 4 & 3.5 \\
\hline Financial problem & 7 & 6.2 \\
\hline \multicolumn{3}{|l|}{ The cause of the first dose } \\
\hline Curiosity & 36 & 27.1 \\
\hline Boredom & 5 & 3.8 \\
\hline A lot of money & 15 & 11.3 \\
\hline Bad friends & 66 & 49.6 \\
\hline Hard work & 11 & 8.3 \\
\hline \multicolumn{3}{|l|}{ The time of the urgent desire to use substance } \\
\hline Anxiety time & 34 & 25.6 \\
\hline Happy time & 27 & 20.3 \\
\hline Leisure time & 35 & 26.3 \\
\hline Grief time & 37 & 27.8 \\
\hline
\end{tabular}


Table (2): Cont. Distribution of the studied substance abusers according to their clinical characteristics $(\mathrm{n}=133)$

\begin{tabular}{|c|c|c|}
\hline \multirow{2}{*}{ Clinical characteristics } & \multicolumn{2}{|c|}{ Studied substance abusers } \\
\hline & No. & $\%$ \\
\hline $\begin{array}{l}\text { Complaint of any physical diseases } \\
\text { Yes } \\
\text { No }\end{array}$ & $\begin{array}{c}19 \\
114\end{array}$ & $\begin{array}{l}14.3 \\
85.7\end{array}$ \\
\hline $\begin{array}{l}\text { Type of disease ( } 19 \text { ) } \\
\text { Diabetes mellitus } \\
\text { Hypertension } \\
\text { Viral hepatitis } \\
\text { Dental problems } \\
\end{array}$ & $\begin{array}{c}1 \\
1 \\
12 \\
5\end{array}$ & $\begin{array}{r}5.3 \\
5.3 \\
63.2 \\
26.3 \\
\end{array}$ \\
\hline $\begin{array}{l}\text { Complaint of any psychological symptoms } \\
\text { Tension and anxiety } \\
\text { Lake of concentration } \\
\text { Sleep problems }\end{array}$ & $\begin{array}{l}54 \\
34 \\
45 \\
\end{array}$ & $\begin{array}{l}40.6 \\
25.6 \\
33.8\end{array}$ \\
\hline $\begin{array}{l}\text { Complaint of any mental illness } \\
\text { Yes } \\
\text { No }\end{array}$ & $\begin{array}{c}30 \\
103 \\
\end{array}$ & $\begin{array}{l}22.6 \\
77.4\end{array}$ \\
\hline $\begin{array}{l}\text { Type of mental illness ( } 30 \text { ) } \\
\text { Obsession } \\
\text { Schizophrenia } \\
\text { Depression } \\
\text { Mania } \\
\text { Anxiety disorders }\end{array}$ & $\begin{array}{c}6 \\
5 \\
12 \\
1 \\
6\end{array}$ & $\begin{array}{c}20.0 \\
16.7 \\
40.0 \\
3.3 \\
20.0\end{array}$ \\
\hline $\begin{array}{l}\text { Family history of substance abuse } \\
\text { Yes } \\
\text { No }\end{array}$ & $\begin{array}{l}46 \\
87\end{array}$ & $\begin{array}{l}34.6 \\
65.4 \\
\end{array}$ \\
\hline $\begin{array}{l}\text { Number of admission to addiction treatment } \\
\text { department } \\
\text { Not once } \\
\text { Once } \\
\text { Twice } \\
\text { More }\end{array}$ & $\begin{array}{l}81 \\
27 \\
14 \\
11\end{array}$ & $\begin{array}{c}60.9 \\
20.3 \\
10.5 \\
8.3\end{array}$ \\
\hline $\begin{array}{l}\text { Number of times you have been arrested by the } \\
\text { police } \\
\text { Not once } \\
\text { Once } \\
\text { Twice } \\
\text { More }\end{array}$ & $\begin{array}{l}85 \\
26 \\
10 \\
12\end{array}$ & $\begin{array}{c}63.9 \\
19.5 \\
7.5 \\
9.0\end{array}$ \\
\hline
\end{tabular}


Table (3): Distribution of levels of social functioning dimensions among the studied substance abusers $(\mathrm{n}=133)$

\begin{tabular}{|c|c|c|c|c|}
\hline \multirow{3}{*}{ Social functioning dimensions } & \multicolumn{4}{|c|}{ Levels } \\
\hline & \multicolumn{2}{|c|}{ High } & \multicolumn{2}{|c|}{ Low } \\
\hline & No. & $\%$ & No. & $\%$ \\
\hline Social engagement / withdrawal & 77 & 57.9 & 56 & 42.1 \\
\hline Interpersonal functioning & 90 & 67.7 & 43 & 32.3 \\
\hline Prosocial activities & 15 & 11.3 & 118 & 88.7 \\
\hline Recreational activities & 18 & 13.5 & 115 & 86.5 \\
\hline Independence competence & 84 & 63.2 & 49 & 36.8 \\
\hline Independence performance & 56 & 42.1 & 77 & 57.9 \\
\hline Employment & 70 & 52.6 & 63 & 47.4 \\
\hline
\end{tabular}

Figure (1): Levels of overall social functioning among the studied substance abusers ( $\mathrm{n}=$ 133) 


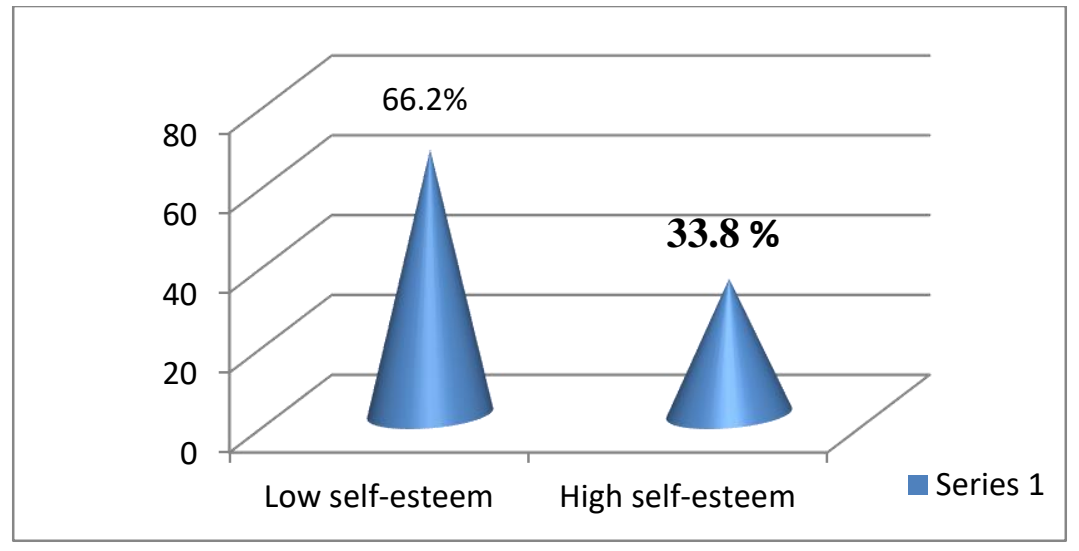

Figure (2): Levels of self-esteem among the studied substance abusers $(n=133)$

Table (4): Correlation between total score of social functioning dimensions and total score of self-esteem among the studied substance abusers $(\mathrm{n}=133)$

\begin{tabular}{||l|c|c||}
\hline \multirow{2}{*}{ Social functioning dimensions } & \multicolumn{2}{c|}{ Total self-esteem } \\
\cline { 2 - 3 } & $\mathbf{r}$ & $\mathbf{p}$ \\
\hline Social withdrawal/engagement & 0.072 & 0.411 \\
\hline Interpersonal functioning & $0.284^{*}$ & $0.001^{*}$ \\
\hline Prosocial activities & $0.267^{*}$ & $0.002^{*}$ \\
\hline Recreational activities & $0.248^{*}$ & $0.004^{*}$ \\
\hline Independence competence & 0.008 & 0.926 \\
\hline Independence performance & $0.191^{*}$ & $0.028^{*}$ \\
\hline Employment & 0.149 & 0.089 \\
\hline
\end{tabular}

r: Pearson coefficient

*: Statistically significant at $\mathbf{p} \leq \mathbf{0 . 0 5}$

Table (5): Correlation between overall social functioning and total self-esteem among the studied substance abusers $(\mathrm{n}=133)$

\begin{tabular}{||c|c|c|}
\hline \multirow{2}{*}{ Items } & \multicolumn{2}{|c|}{ Total self-esteem } \\
\cline { 2 - 3 } & $\mathbf{r}$ & $\mathbf{p}$ \\
\hline \hline Overall Social Functioning & $0.263^{*}$ & $0.002^{*}$ \\
\hline
\end{tabular}




\section{DISCUSSION:}

Substance abuse disturbs social functioning symptoms as social isolation, decreased intimate interactions, diminished physical engagement, failure to survive on one's own, and lack of productivity at work. Such incompetence decreases the family; occupational and social performance of patients causes economic damages and reduces the quality of life of patients (Can \&Tanrıverdi, 2015). Self-esteem is a significant determinant of mental health and development (Wang \& Veugelers, 2008). It is the most consistent predictors of the likelihood and context of substance abuse, it was evidence that low self-esteem contributes to substance abuse (Kitinisa, 2019).

Therefore, this study is conducted to explore the relation between the levels of social functioning and self-esteem among substance abusers through determining social functioning levels, assessing self-esteem levels, and finding out the correlation between social functioning and self-esteem among substance abusers.

The present study showed that almost three-quarters of the studied substance abusers had a low level of social functioning. This may be due to that the substance abusers became dependent on substances, thus gave more priority to the substances, neglecting their functions in other areas, especially impairment was seen in their work functioning and family functioning. They may become socially isolating or may be concealed from friends or close relatives, and didn't engage in any recreational activities.

This finding was consistent with Shayna, Greenwald, Carter \& Stein (2015), who reported a low social functioning level among substance abusers. Whereas, this finding was in disagreement with a study carried out in Eastern Turkey by Ersöğütçü\&Karakaş, (2016) who found that substance abusers had a medium level of social functioning. In addition, Aditi\&Arunjyoti, (2018) found that the majority of patients diagnosed with substance use disorders had a level of social functioning that deviated from the satisfactory level, and they had a moderate level of social functioning.

The conflicts, guilt trips, and dissatisfactions encountered by substance abuse negatively affect the self-esteem of the substance abuser. The finding of the present 
study denoted that about two-thirds of the studied substance abusers had a low level of self-esteem. This probably due to that more than half of the studied subjects had family problems which negatively affect their self-esteem level as they felt not to be loved by their family members and not accept their qualities and themselves at all. Thus, people with poor self-esteem prefer to use the drug to fulfill their desire for selfesteem and to regulate their feelings and behavior.

In congruence with this finding, Akhter (2013), who studied the relationship between substance use and self-esteem in Pakistan, and reported that low self-esteem was associated with high substance use. In this respect, a study done by Abbo, Okello, Muhwezi, Akello \& Ovuga, (2016), asserted that more than two-thirds of substance abusers had low self-esteem. Also, the abovementioned present result was similar to a Turkish study by Zengin \& Altay, (2014), which revealed that substance abuse lowers self-esteem.

In contrast with the previous finding, Ikechukwu, Siti, Talib, Mofrad, \& Abdullah (2013) who illustrated that most of the substance abusers reported a high self-esteem level. This finding is in line with the study carried out at the Al-Amal Hospital in Jeddah by Hasan (2019), who found a positive relationship between selfesteem and substance abuse.

The main objective of the present study was to explore the relation between the levels of social functioning and self-esteem among substance abusers. The findings revealed that there was a statistically significant positive correlation between overall social functioning and total self-esteem among the studied substance abusers. It can be argued that low self-esteem among substance abusers has played a crucial role in the development of social issues as depression, anxiety, violence, negative insights, and detachment from social relations that adversely impact social activity, disturbs social cohesion, and trigger unpleasant social experiences and incompetence in social life.

This finding has been supported by a study carried out in Eastern Turkey by Ersöğütçü \& Karakaş, (2016), who showed a positive significant correlation between social functioning and self-esteem. Similarly, a study by Radu, Chiriţă, Borza, Macarie, Nuc \& Paziuc, (2015), who reported a strong correlation between social functioning and self-esteem. Also, this finding is in line with the study by Ahmad, Bano, Ahmad \& Khanam, (2013), who stated a positive significant correlation 
between social functioning and self-esteem. However, this finding has been unsupported by a study carried out in Turkey by Can \& Tanriverdi, (2015), who reported a negative significant association between self-esteem and social functioning among substance abusers.

\section{CONCLUSION:}

Based on the findings of the current study, it can be concluded that the majority of the studied substance abusers had low levels of social functioning. In addition, about two-thirds of them had a low level of self-esteem. Finally, there was a statistically significant positive correlation between overall social functioning and total self-esteem among the studied substance abusers.

\section{RECOMMENDATIONS:}

\section{Based on the findings of the current study, it can be recommended that:}

Psychosocial intervention should be addressed to substance abusers to improve particular areas of social functioning, such as communication, interpersonal relationships, and employment.

Continuous psycho-educational programs should be provided to substance abusers to empower them to improve their self-esteem. These programs should be led by health professionals, especially nurses and psychologists.

Rehabilitation programs for substance abusers should include counseling services in order to improve their social functioning and enhance their self-esteem are crucial.

Family therapy by professionals like psychologists, social workers, and qualified counselors should be encouraged to help in teaching families ways of educating their substance abusers about ways of dealing with the negative outcomes of substance abuse.

Psychiatric nurses, particularly those working at substance abuse centers, have essential roles such as encouraging and monitoring therapeutic group activities such as morning greetings and guidance for work, occupation, sports, books, and travel which enable personal development and enhance self-esteem, entrepreneurship, and social functioning. 


\section{REFERENCES:}

Abbo, C., Okello, E. S., Muhwezi, W., Akello, G., \& Ovuga, E. (2016). Alcohol, substance use and psychosocial competence of adolescents in selected secondary schools in Uganda: A cross sectional survey. International Neuropsychiatric Disease Journal, 7 (2), 25387.

Aditi, B., \&Arunjyoti, B. (2018). Addiction severity, social functioning, and life satisfaction of patients diagnosed with substance use disorders. Indian Journal of Psychiatric Nursing, 15 (2), 13.

Ahmad, Z. R., Bano, N., Ahmad, R., \& Khanam, S. J. (2013). Social anxiety in adolescents: Does self-esteem matter. Asian Journal of Social Sciences and Humanities, $2(2), 91-98$.

Akhter, A. (2013). Relationship between substance use and self-esteem. International Journal of Scientific \& Engineering Research, 4 (2), 65-79

Atta, M. H.R (2017). Dimensions of emotional regulation difficulties and areas of social functioning among patients with schizophrenia. Unpublished Master Thesis. Alexandria University; Faculty of Nursing, Egypt. 71-78.

Birchwood, M., Smith, J., Cochrane, R., Wetton, S., \& Copestake, S. (1990).The social functioning scale. The development and validation of a new scale of social adjustment for use in family intervention programs with schizophrenic patients. British Journal of Psychiatry, (157), 853-859.

Can, G., \& Tanrıverdi, D. (2015). Social functioning and self -esteem in individuals diagnosed with substance use disorder. Archives of Psychiatric Nursing, 29 (6), 441- 446.

China National Narcotics Control Commission (2013). Annual report on drug control in China. Beijing: Ministry of Public Security, 115-123.

Daley, D. C. (2013). Family and social aspects of substance use disorders and treatment. Journal of food and drug analysis, 21(4), S73-S76.

Dobson, AJ. (1984). Calculating sample size, Trans Menziez Foundation; 75. 
Ebrahimi, H., Navidian, A., \& Keykha, R. (2014). Effect of supportive nursing care on self -esteem of patients receiving electroconvulsive therapy: a randomized controlled clinical trial. Journal of caring sciences, 3 (2), 149-156.

Ersögütçü, F., \& Karakaş, S. A. (2016). Social functioning and self-esteem of substance abuse patients. Archives of Psychiatric Nursing, 30 (5), 587-592.

Hamdi, E., Sabry, N., Sedrak, A., Khowailed, A., Loza, N., Rabie, M., \& Ramy, H. (2016). Socio-demographic indicators for substance use and abuse in Egypt. Journal of Addiction \& Prevention, 4 (1), 1-8.

Hasan, A. A. (2019). The impact of substance misuse disorder on psychosocial aspects of patients' lives. Mental Health Addiction Research, 4 (3), 145-163.

Ikechukwu, U., Siti, N. Y., Talib, M. A., Mofrad, S., \& Abdullah, R. (2013). Effect of self-esteem in the relationship between stress and substance abuse among adolescents: A mediation outcome. International Journal of Social Science and Humanity, 3 (3), 214-217.

Kitinisa, P. (2019). Self-Esteem, depression and substance abuse among school going adolescents, Unpublished Dissertation, Makerere University, 54-73.

National Institute of Drug Abuse (2008). Adolescent substance use: America's public health problem. Retrieved August 15, 2017, from http://www.eric.ed.gov/PDFS/ED521379. pdf.

Radu, M. R., Chiriță, R., Borza, L. R., Macarie, G. F., Nuc, G., \& Paziuc, L. C. (2015). The role of self-esteem and autonomy in improving social functioning in substance abuser: A matter of dignity. Revista Romana de Bioetica, 13 (1), 119-136.

Rosenberg, M. (1989). Society and the adolescent self-image. Middletown, CT: Wesleyan University Press, 225-234.

Shayna, R., Greenwald, J., Carter, S., \& Stein, E. M. (2015). Differences between the background, attitude, functioning, and mood of drug addicts, alcoholics, and orthopedic patients. International Journal of the Addictions, 1, 865-874 
Van Kleef, R., van Donkersgoed, R., \& de Jong, S. (2015).Metacognition in Relation to Cognitive and Social Functioning in Schizophrenia. Journal of European Psychology Students, 6 (3).

Wang, F., \& Veugelers, P. (2008).Self-esteem and cognitive development in the era of the childhood obesity epidemic. Obesity Review, (9), 615-23. Retrieved September 12, 2017, from http://www.nida.nih.gov.

World Health Organization (2017). Retrieved November 18, 2017, from http://www.who.int/topics/substance_abuse/en/.

Zaidi, U., Awad, S. S., Mortada, E. M., Qasem, H. D., \& Kayal, G. F. (2015). Psychometric evaluation of Arabic version of Self-Esteem, Psychological Well-being and Impact of weight on Quality of life questionnaire (IWQOL-Lite) in female student sample of PNU. European Medical, Health and Pharmaceutical Journal, 8(2).

Zengin, S., \& Altay, B. (2014). Examining the self-esteem of the students studying in the section of forget class. Gümüşhane University Journal of Health Sciences, 3 (3), 892-907. 


\section{الأداء الإجتماعي وتقدير الأات لاي متعاطي المخدرات في مستثفى الصحة النفسية ببورسعيد}

\section{محمد السيا محمد محمد اليمني1، أ.د / أمل صبحي محمود 2 ،د / نادية محمد وهبة3}

ماجستير التمريض النفسى و الصحة العقلية ،كلية التمريض جامعة بورسعيد 1، أستاذ التمريض النفسى والصحة العقلية

،كلية التمريض جامعة بورسعيد²، مدرس التمريض النفسى و الصحة العقلية ،كلية التمريض جامعة بورسعيد3

\section{الخلاصة}

يشير تعاطي المخدرات إلى سوء الاستخدام المدمر أو الخطير للمو اد التي تحتوي على الكحول و المخدرات غير

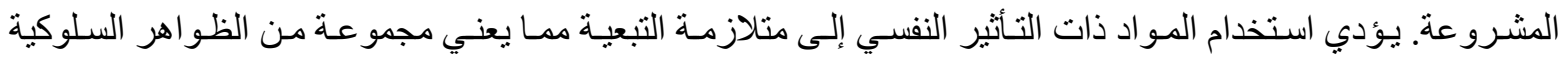
و المعرفية والفسيولوجية التي تتطور بعد الاستخدام المتكرر للمو اد المخدرة والتي تتطوي عادة على رغبة قوية في تتاول المخدر ، وصعوبات التحكم في استخدامه، والاستمر ار في استخدامه على الر غم من العو اقب الضـارة، وأولويـة أعلى لتعاطي المو اد المخدرة من الأنشطة والو اجبات الأخرى.

تبرز مشكلة تعاطي المخدر ات كمسألة اجتماعية تؤثر سلبًا على الأداء الاجتماعي وتعطل الانسجام الاجتماعي وتسبب سلبية في العلاقات الإجتماعية. الأداء الاجتماعي هو القدرة على العمل، و الحفاظ على العلاقات الثخصية ور عاية الذات.

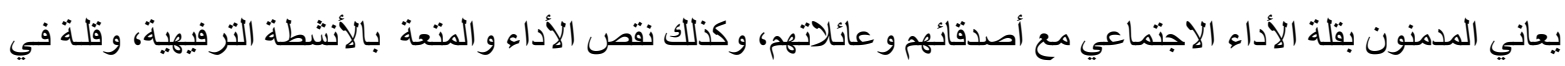
الاستقلال الذاتي للحفـاظ على أداء المهام المكلفين بها، وسـوء الأداء المعرفي وقلـة في ممارسـة المهار ات و الأنشطة الإجتماعية.

إن أحد أهم مؤشرات الصـحة النفسية هو تقدير الذات، الذي يميز البعد العـاطفي للذات، ممـا يعني قبول الذات، و إحتر امها والشعور بقيمتها الحقيقية. تقدير الذات هو مصطلح يُعرف كيفية تقييم البشر أنفسـهم بشكل عام. كما يمكن وصفه بأنه الثقة التي يتمتع بها الفردو الرضا عن شخصيته. إن الأشخاص اللذين لديهم شعور بنقص تقدير الذات لديهم ميل نحو تعاطى المو اد المخدرة كوسيلة للتعامل مع المشاعر السلبية إتجاه الذات و الهروب من الضغوط النفسية. 